\title{
Dipylidium caninum (Cyclophyllidea, Dipylidiidae) in a Wild Carnivore from Brazil
}

Author(s): Fabiano M. Vieira, José L. Luque, Sueli de Souza Lima, Antonio H. A. de Moraes Neto, and Luís C. Muniz-Pereira

Source: Journal of Wildlife Diseases, 48(1):233-234.

Published By: Wildlife Disease Association

DOI: http://dx.doi.org/10.7589/0090-3558-48.1.233

URL: http://www.bioone.org/doi/full/10.7589/0090-3558-48.1.233

BioOne (www.bioone.org) is a nonprofit, online aggregation of core research in the biological, ecological, and environmental sciences. BioOne provides a sustainable online platform for over 170 journals and books published by nonprofit societies, associations, museums, institutions, and presses.

Your use of this PDF, the BioOne Web site, and all posted and associated content indicates your acceptance of BioOne's Terms of Use, available at www.bioone.org/page/ terms of use.

Usage of BioOne content is strictly limited to personal, educational, and non-commercial use. Commercial inquiries or rights and permissions requests should be directed to the individual publisher as copyright holder. 


\section{Dipylidium caninum (Cyclophyllidea, Dipylidiidae) in a Wild Carnivore from Brazil}

Fabiano M. Vieira, ${ }^{1,6}$ José L. Luque, ${ }^{2}$ Sueli de Souza Lima, ${ }^{3}$ Antonio H. A. de Moraes Neto, ${ }^{4}$ and Luís C. Muniz-Pereira $^{5}{ }^{1}$ Programa de Pós-Graduação em Biologia Animal, Universidade Federal Rural do Rio de Janeiro, Rodovia BR 465 - Km 7, CEP 23890-000, Seropédica, Rio de Janeiro, Brazil; ${ }^{2}$ Departamento de Parasitologia Animal, Universidade Federal Rural do Rio de Janeiro, Caixa Postal 74508, CEP 23851-970, Seropédica, Rio de Janeiro, Brazil; ${ }^{3}$ Departamento de Zoologia, Laboratório de Taxonomia e Ecologia de Helmintos, Universidade Federal de Juiz de Fora, Bairro Martelos, CEP 36036-330, Juiz de Fora, Minas Gerais, Brazil; ${ }^{4}$ Laboratório de Inovações em Terapias, Ensino e Bioprodutos, Instituto Oswaldo Cruz, FIOCRUZ, Avenida Brasil 4365, CEP 21040-900, Rio de Janeiro, Rio de Janeiro, Brazil; ${ }^{5}$ Laboratório de Helmintos Parasitos de Vertebrados, Instituto Oswaldo Cruz, FIOCRUZ, Avenida Brasil 4365, CEP 21040-900, Rio de Janeiro, Rio de Janeiro, Brazil; ${ }^{6}$ Corresponding author (email: fmatosvieira@ gmail.com)

ABSTRACT: We report Dipylidium caninum for the first time in a wild carnivore in Brazil, the crab-eating fox (Cerdocyon thous). Presence of the cestode could be the consequence of anthropogenic expansion into natural habitats of this host, as this parasite has only previously been reported in domestic hosts in Brazil.

Dipylidium caninum (Linnaeus, 1758; Cyclophyllidea, Dipylidiidae) is a cestode of domestic dogs (Canis lupus familiaris) and cats (Felis catus), some wild carnivores, and occasionally humans around the world (Schmidt and Roberts, 2000). Two extensive reports on cestodes in wild carnivores in Brazil (Travassos, 1965; Vieira et al., 2008) do not include this species, which has only been found in domestic dogs and cats (Travassos, 1965; Dantas-Torres, 2008). A similar pattern is seen in other South American countries, as this cestode is reported only in the pampas fox (Lycalopex gymnocercus; Carnivora, Canidae) in Argentina (Lucherini and Vidal, 2008). We provide the first report of $D$. caninum in a wild crab-eating fox, Cerdocyon thous (Carnivora, Canidae), in Brazil.

Dead crab-eating foxes from the municipality of Juiz de Fora $\left(21^{\circ} 41^{\prime} 20^{\prime \prime} \mathrm{S}\right.$, $\left.43^{\circ} 20^{\prime} 40^{\prime \prime} \mathrm{W}\right)$, State of Minas Gerais, Brazil, were collected by the Screening Center for Wild Animals in Juiz de Fora (CETAS/JF), which is maintained by the Brazilian Institute for the Environment and Renewable Natural Resources (IBAMA), and sent to the Zoology Department of the Universidade Federal de Juiz de Fora (UFJF) between 2007 and 2009 .
Six crab-eating foxes were necropsied. Cestodes were fixed in alcohol-formaldehydeacetic acid (AFA; 70\% ethanol, 93 parts; 37\% formalin, 5 parts; glacial acetic acid, 2 parts) for 48 hr, stained with Mayer's carmalum (Humason, 1979) and mounted in Canada balsam for examination as whole mounts. Identification of the cestode was based on Witenberg (1932) and Khalil et al. (1994). The intensity of infection was four adult parasites in the small intestine of one adult female $C$. thous. Voucher specimens of $D$. caninum were deposited in the Helminthological Collection of Oswaldo Cruz Institute (CHIOC No. 37581).

Several species of cestodes have been reported in wild carnivores in Brazil (Travassos, 1965; Vieira et al., 2008, Pinto et al., 2009, Muniz-Pereira et al., 2009), and the cestodes in crab-eating fox in Brazil include: Mesocestoides michaelseni Loemberg, 1896 (Cyclophyllidea, Mesocestoididae), Spirometra mansoni (Cobbold, 1883) (Pseudophyllidea, Diphyllobothriidae; = Diphyllobothrium mansoni) and Spirometra mansonoides Muller, 1935 (= Diphyllobothrium mansonoides; Vieira et al., 2008). The crab-eating fox is the host species with the largest number of records of helminthes among wild carnivores in Brazil (Vieira et al., 2008).

Infection by $D$. caninum is generally asymptomatic. However, some infected domestic dogs may drag their rump across the floor as a consequence of the perianal pruritus caused by the movement of gravid 
proglottids in the anus of the host (DantasTorres, 2008). In domestic cats, severe infection by $D$. canimum may lead to seizures and epilepsy (Bowman et al., 2002).

The crab-eating fox is found throughout Brazil, with the exception of the Amazon region. It is typically a generalist species with opportunistic habits, occupying a large variety of habitats. The diet is composed of small invertebrates, small vertebrates and fruit, but this fox will occasionally feed on carrion and garbage (Courtenay and Maffei, 2004).

Habitat destruction is the greatest threat to biological diversity worldwide. The fragmentation of forests is directly related to anthropogenic effects stemming from agricultural expansion (Primack and Rodrigues, 2001; Michalski and Peres, 2005). Therefore, this first record of parasitism by D. caninum in C. thous in Brazil may be the result of anthropogenic expansion into the natural habitats of this host.

We thank the Screening Center for Wild Animals in Juiz de Fora (CETAS/JF), which is maintained by the Institute for the Environment and Renewable Natural Resources (IBAMA). J. L. Luque was supported by a research fellowship from the Brazilian fostering agency Conselho Nacional de Desenvolvimento Científico e Tecnológico do Brasil (CNPq). F. M. Vieira was supported by a student fellowship from REUNI/UFRRJ (Programa de Apoio ao Plano de Reestruturaão e Expansão das Universidades Federais, Brazil).

\section{LITERATURE CITED}

Bowman, D. D., C. M. Hendrix, D. S. Lindsay, and S. C. BArr. 2002. Feline Clinical Parasitology. Iowa State University Press, Iowa, USA, 469 pp.

Courtenay, O., and L. Maffei. 2004. 3.2 Crab-eating fox. Cerdocyon thous (Linnaeus, 1766). In Canids: Foxes, wolves, jackals and dogs. Status survey and conservation action plan, C. Sillero-Zubiri,
M. Hoffman and D. W. Macdonald (eds.). International Union for Conservation of Nature The World Conservation Union, Gland, Switzerland, pp. 32-38.

Dantas-Torres, F. 2008. Canine vector-borne diseases in Brazil. Parasites and Vectors 1: 25.

Humason, G. L. 1979. Animal tissue techniques, 4th Edition. W. H. Freeman and Company, San Francisco, California, 661 pp.

Khalil, L. F., A. Jones, and R. A. Bray. 1994. Key to the cestodes of vertebrates. CAB International, Wallingford, USA, $751 \mathrm{pp}$.

Lucherini, M., And E. M. L. Vidal. 2008. Lycalopex gymnocercus (Carnivora: Canidae). Mammalian Species 820: 1-9.

Michalski, F., and C. A. Peres. 2005. Anthropogenic determinants of primate and carnivore local extinctions in a fragmented forest landscape of southern Amazonia. Biological Conservation 124: 383-396.

Muniz-Pereira, L. C., F. M. Vieira, and J. L. Luque. 2009. Checklist of helminth parasites of threatened vertebrate species from Brazil. Zootaxa 2123: 1-45.

Pinto, R. M., M. Knoff, A. Q. Gonalves, M. Sanches, and D. Noronha. 2009. First report of Taenia mustelae (Eucestoda, Taeniidae) parasitizing the bushy-tailed olingo, Bassaricyon gabbii (Carnivora, Procyonidae) in South America with an updated checklist of cestodes from other American Procyonid hosts. Neotropical Helminthology 3: 7-14.

Primack, R. B., and E. E. Rodrigues. 2001. Biologia da Conservaão. Editora Midiograf, Londrina, Brasil, 328 pp.

Schmidt, G. D., and L. S. Roberts. 2000. Foundations of Parasitology (6th Edition). McGrawHill, Boston, Massachussets, 670 pp.

Travassos, L. 1965. Contribuião para o inventário crítico da zoologia no Brasil. Fauna helmintológica: Consideraões preliminares - Cestódeos. Publicaões Avulsas do Museu Nacional, Rio de Janeiro, Brazil, 84 pp.

Vieira, F. M., J. L. Luque, and L. C. Muniz-Pereira. 2008. Checklist of helminth parasites in wild carnivore mammals from Brazil. Zootaxa 1721: $1-23$.

WitenberG, G. 1932. On the cestode subfamily Dipylidiinae Stiles. Zeitschrift fur Parasitenkunde 4: 542-584.

Submitted for publication 6 July 2011.

Accepted 9 August 2011. 